\title{
The Harry S. Truman Library as a Center for Research on the American Presidency
}

\author{
BY PHILIP D. LAGERQUIST
}

WHEN George Washington, having turned over the presidential office to John Adams, left Philadelphia on March 9, 1797 , to travel, as he put it, "through mud and mire to reach more tranquil scenes at Mount Vernon"1 he took with him, along with his other chattels, the files he had accumulated during eight years' service as chief executive, thus setting a precedent which was to be followed by each of his successors. In so doing the Father of his Country did nothing improper or illegal. The presidency is unique in that, with the exception of the vicepresidency, it is the only office in the executive branch of the government to have been created by the Constitution and not by statute. For this reason presidential papers have a privileged status. They are confidential files, intimately involved in the presidential decision-making process. To consider them part of the official public record would run counter to the concept of a government based on a separation of powers, which lies at the very heart of the American Constitution. The validity of this thesis is attested by the fact that the right of an outgoing president to take his files with him has never been successfully challenged in the courts.

The shipment of Washington's papers from Philadelphia to Mount Vernon re-

\footnotetext{
1 Letter from George Washington to Matthias Slough, Feb. 6, 1797, The Writings of George Washington From the Original Manuscript Sources, 17451799, ed. John C. Fitzpatrick ( 39 vols.) Washington: U.S. Government Printing Office, 1940), XXXV, p. 385 .
}

Mr. Lagerquist is Research Archivist in the Harry S. Truman Library, Independence, Missouri.

quired the use of only a few trunks, cartons, boxes, and the like, even though these documents represented the record of executive action during nearly a decade. Over the years, however, with the growth of the republic in area and in population, with the development of modern means of communication, especially the typewriter, with the increased literacy of the electorate, and with the increase in the size and responsibilities of the presidential office year after year, the number of individual items in collections of presidential papers has multiplied until, in the case of our modern-day chief executives they are numbered in the millions. While such documents are legally the president's property, they are, nevertheless, files in which the entire nation has a vested interest, for they are the only record we possess of the daily actions and decisions of our chief executive and as such are an invaluable and irreplaceable source of information for scholars investigating the history of our country. It is unfortunate, therefore, that the papers of many of our presidents have been willfully or accidentally destroyed or are in depositories scattered from one end of the country to the other. The Library of Congress, our greatest manuscript-holding institution, has, at present, twenty-three collections of presidential papers, sixteen of these being 
of a substantial nature. The number of manuscripts in even the largest collections of presidential papers in the Library of Congress, however, is relatively small when compared with those of our most recent presidents. The largest of the library's collections, the Taft papers, comprises approximately half a million items. In contrast, the Truman papers consist of well over five million pages, while the Franklin D. Roosevelt collection is even larger. The processing and servicing of collections of this size so that they can be made available to researchers is a job of considerable magnitude, which, under ideal conditions, calls for a trained staff which can devote its full attention to work on the collection. There was a time, long past, when a president could hope upon retirement to arrange his papers himself. Washington, several years after leaving office, wrote a friend that he was devoting his leisure hours to "the arrangement and overhaul of my voluminous Public $\mathrm{Pa}$ pers, Civil and Military, that they may go into secure deposits, and hereafter, into hands that may be able to seperate [sic] the grain from the chaff." 2 Our modernday presidents, however, have neither the time nor the staff assistance to undertake such a task, considering the magnitude and scope of their files. This is a job which can be successfully undertaken only by persons experienced in the care of archival collections.

Moreover, in addition to their papers, our presidents also take with them when they leave the White House the many books and gifts presented to them during their terms of office, and provision must also be made for the disposition of these items. While in the past the papers, books, and mementos of former presidents have often been divided among a number of institutions for safekeeping, our most recent presidents have adopted the concept of the individual presidential library, relating to a single administration,

${ }^{2}$ Ibid., Letter from George Washington to the Secretary of War, July 29, 1798, XXXVI, pp. 373-74. as the best method of preserving for future generations the interrelated historical materials pertaining to each administration. The archetype of the present-day presidential library is the Hayes Memorial library and museum, at Fremont, Ohio. The Hayes library, which was opened on May 30, 1916, was built to house the papers and memorabilia of President Rutherford B. Hayes. Erected by the state of Ohio, it is maintained and operated under the joint supervision of the state and the Hayes Foundation. It was followed by the Franklin D. Roosevelt library which was opened to the public in 1941 , the first such institution to be operated by the federal government. With the passage by Congress of the Presidential Libraries Act of 1955 , permanent provision was made by Congress for the housing and care of the papers, books, and gifts of any president who wished to present them to the nation. Under the provisions of this Act the papers and other historical materials of presidents Herbert Hoover, Harry S. Truman, and Dwight D. Eisenhower are now deposited in libraries bearing their name, and a Kennedy library is now in the planning stage. Each of these libraries is staffed and operated by the National Archives and Records Service of the General Services Administration, and they are thus a part of the government's nationwide recordkeeping system.

Many consider Harry S. Truman the most history-minded of our recent presidents, and so it is perhaps fitting that the first institution to be established under permanent presidential library legislation was built to house his papers. In his Memoirs Mr. Truman states that "the one great external influence which, more than anything else, nourished and sustained [my] interest in government and public service was the endless reading of history which I began as a boy and which I have kept up ever since." 3 Conscious of his

${ }^{3}$ Harry S. Truman, Memoirs, Vol. I: Year of Decisions (New York: Doubleday and Co., 1955), p. 119. 
own debt to history and to the historical profession, Mr. Truman was particularly concerned about the ultimate disposition of his own papers after his departure from the White House. After much cogitation and consultation with friends and members of the White House staff, he decided to follow the precedent set by Franklin D. Roosevelt, and turn over his files to the custody of the federal government, to be housed in a building erected for that purpose in Independence, Missouri, the town where he had lived the greater part of his life. The building was to be built with money raised by private subscription, and for this purpose a nonprofit corporation was formed. An intensive drive for building funds, begun in 1953 shortly after Mr. Truman's departure from the White House, resulted in contributions from more than seventeen thousand individuals and organizations, and by the time the building was completed the goal of $\$ 1,750,000$ had been surpassed.

The Truman library was formally dedicated on July 6, 1957, by Chief Justice Earl Warren in the presence of dignitaries representing both major political parties and including former President Herbert Hoover, Mrs. Franklin D. Roosevelt, former Secretary of State Dean Acheson, and several thousand other citizens. During the course of the ceremonies President Truman presented to Dr. Wayne C. Grover, Archivist of the United States, a document attesting the legal transfer to the nation of his papers and other historical materials "to the end that the people may have those things available for study and research and for their enjoyment and education." 4

The new building, which by the former president's generous action had become the property of the nation, is a one-story structure of Indiana limestone. It is located in a tract of thirteen and two-tenths

\footnotetext{
4 Letter from Harry S. Truman to Franklin F. Floete, Administrator, U.S. General Services Administration, Feb. 12, 1957.
}

acres about one mile from the center of Independence. Shaped roughly like the letter "J," the building is six hundred feet long and has a full basement. One end of the structure is devoted to a public museum. Here are displayed many gifts, valuable and otherwise, which were presented to Mr. Truman when he occupied the White House, as well as documents from the White House files chosen for their illustrative value. The main theme of the exhibits is the nature and history of the presidential office. While the exhibit items, with few exceptions, originally belonged to Mr. Truman, the exhibits, in accordance with the former president's wishes, are designed, not to glorify him, but to explain in meaningful terms the scope of our chief executive's manifold duties. Adjacent to the museum is an auditorium seating 250 persons which is used for showing films from the library's motion picture collection and for meetings of scholarly organizations interested in the library's activities. Here, also, members of the staff, and sometimes Mr. Truman himself, talk to groups of school children who come to tour the museum.

The central portion of the building contains the library's research facilities. In this area are the stacks; a central research room where scholars can examine the library's historical materials; staff offices; a microfilm reading room; and a photographic laboratory. While the entire building is air-conditioned, the stack areas have, in addition, special temperature and humidity controls for protection of the papers. The director of the library, Philip C. Brooks, supervises a staff of fifteen, including six professional archivists. Custodial and maintenance personnel are supplied by the General Services Administration's Public Buildings Service.

As far as the general public is concerned, the museum is the library's focal point of interest. The library, however, is first and foremost a research institution. Established as a depository for the White 
House files of the Truman administration, the most important task of the library's staff is to make these materials available to responsible scholars. To this end the Truman papers have been removed from their original file cases, placed in lightweight archives boxes, arranged, listed, and shelved in appropriate order. In addition to the main body of White House papers, files transferred to the government by $\mathrm{Mr}$. Truman include such ancillary materials as the records of the White House official reporter, the records of the White House social office, and the files of a number of the members of Mr. Truman's White House staff. Also included in Mr. Truman's gift were his senatorial papers, and the papers accumulated by him during his brief term as vice-president.

To supplement the Truman papers the library has for the past several years been attempting to acquire the papers of personal and political associates of Mr. Truman. To date more than fifty individuals have donated their personal papers to the library, and an equal number have made firm commitments to do so at some future date. The list includes former members of Mr. Truman's cabinet, other officials in the executive branch, members of the independent regulatory agencies, White House staff members, officials of the Democratic National Committee, members of Congress, and persons who were associated with Mr. Truman during the early years of his political career. In a further attempt to fill in gaps in the historical record, the library has recently initiated an oral history project. This involves the interviewing by trained members of the library's staff of persons who held key positions in the Truman administration or who enjoyed the confidence of Mr. Truman at various stages of his career. The interviews are recorded on tape and, after transcription, are made available to researchers.

The library also has an extensive collection of audio-visual materials relating to Mr. Truman and the Truman administration, consisting of more than twenty thousand photographs, thirteen hundred sound recordings, and approximately twenty-two thousand and five hundred feet of motion picture film. The still picture collection has been used extensively, both by those looking for book illustrations and in connection with the preparation of documentary films. Motion pictures from the library's collection have been shown in the library's auditorium from time to time as part of its educational program, and the sound recordings of speeches have been in great demand, both by historians and by students wishing to study Mr. Truman's campaign techniques.

The library's book collection consists of approximately twenty-seven thousand books and twenty-nine thousand pamphlets and other printed items. At the time of the library's dedication the book collection comprised seven thousand items, mostly gifts to Mr. Truman while he was president. In order to increase the usefulness of the book collection as an adjunct to the library's manuscript materials, additional book purchases have for the most part been concentrated in the areas in which the library is specializing. In addition to anything published about Mr. Truman and his associates and about the Truman administration, the library is also purchasing, on a selective basis, books relating to the history and nature of the office of the presidency. These purchases include not only published items but also, when available, microfilm copies of presidential papers in other institutions, notably the Adams papers in the Massachusetts Historical Society and the Library of Congress collection of presidential papers.

Portions of the library's museum collection area are also used by researchers in connection with their work. One item frequently consulted is a large map showing the routes taken by Mr. Truman during the course of his 1948 whistle-stop 
campaign, which at one time hung outside Mr. Truman's White House office and which is now one of the museum's most popular exhibits. Useful to scholars in another way is the museum's collection of more than eight hundred political cartoons. Most of these are originals, presented to Mr. Truman by the artists. They are much in demand for illustrative purposes.

While the director of the library has discretion in the matter, permission to use the library's historical materials is generally granted to persons whose study has a serious and useful purpose and who, preferably, have had previous experience in the use of manuscripts. No one, however, is given privileged access to the files. Those papers which, according to law or the wishes of the donor, must, for reasons of national security or personal propriety, be closed for the time being are closed to all researchers. Nearly onehalf of those who have so far studied at the library have been candidates for the MA or PhD degrees, most of them working in the fields of history or political science. Other researchers at the library have been college professors pursuing advanced scholarly projects, and biographers, journalists, and freelance writers working on books or magazine and newspaper articles. Occasionally a senior honors student, when recommended by his advisor, will be allowed to examine the papers. Generally, however, the staff will suggest that college undergraduates as well as high school students use printed sources as more suitable for their purposes. Prospective researchers are encouraged to write the library in advance of their arrival regarding the nature of their research project so that the staff may ascertain what materials are available on the subject. If the library has nothing on a topic, an attempt is made to let the researcher know where information on the matter can be obtained. After coming to the library and before starting to work, the prospective researcher is interviewed by the director and one of the staff archivists. This gives the staff a better knowledge of the topic to be investigated and gives the researcher an opportunity to learn in detail about the library's holdings.

Students utilizing the library's research facilities have come from all parts of the country. The subjects they have worked on run the range of research possibilities for the Truman period-from Bernard Baruch to Arthur Vandenberg, from antitrust laws to the Taft-Hartley law, from agricultural policy to unification of the armed forces. Although the library has been open for research only since 1959 , an impressive number of dissertations, theses, and books has already appeared based in large part on work done there. As scholarly interest in the Truman period increases and as more papers become available for study, it is anticipated that research interest in the library will grow correspondingly. To encourage such interest, a nonprofit corporation, the Harry S. Truman Library Institute for National and International Affairs, has been formed. The institute, whose members are persons prominent in the fields of education and national affairs, has as its purpose the support of the research activities of the library on a broad scale. Its special interest is a grant-in-aid program whereby monetary grants up to one thousand dollars may be allotted to worthy scholars, especially those who are just beginning their academic careers, for travel and living expenses while they are studying at the library.

In his book, Mr. Citizen, Mr. Truman, in speaking of his part in establishing the library, says: "Nothing that has happened to me during or since the presidency has given me such deep and abiding satisfaction." ${ }^{5}$ The library staff has felt compensated for its many long hours of hard work by seeing the library develop into a full-fledged research institution.

${ }^{5}$ Harry S. Truman, Mr. Citizen (New York: Bernard Geis Associates, c. 1960), p. 259. 